\title{
VIRULENSI JAMUR ENTOMOPATOGEN BEAUVERIA BASSIANA (BALSAMO) VUILLEMIN(DEUTEROMYCOTINA: HYPHOMYCETES) TERHADAP KUTUDAUN (APHIS SPP.) DAN KEPIK HIJAU (NEZARA VIRIDULA)
}

\author{
Indriyati $^{1}$
}

\begin{abstract}
Virulence of entomopathogenic fungi Beauveria bassiana (Balsamo) Vuillemin (Deuteromycotina: Hyphomycetes) on aphid (Aphis spp.) and green stink bug (Nezara viridula). This study was conducted at the Laboratory of Plant Pests and Diseases Department of Plant Protection Faculty of Agriculture, University of Lampung. It was aimed to test the virulence of field and commercial inoculum of B. bassiana on aphid and green stink bug. The field inoculum of B. bassiana was originated from infected grasshoppers and isolated in Biocontrol Laboratory of PT Gunung Madu Plantations, Central Lampung, while the commercial inoculum (Natural BVR) was formulated by PT Natural Nusantara. A single exposure concentration assay (1 $\mathrm{x} 10^{7}$ conidia/ml) for each inoculum was conducted by immersing the insects in fungal suspension for 10 second. The results indicated that the virulence of field and commercial inoculum of $B$. bassiana was significantly different on aphid. The field inoculum B. bassiana was highly virulent and caused $78.8 \%$ mortality, on the contrary the commercial B. bassiana showed low virulence and caused only $27.42 \%$ mortality of aphid. However, both inocula caused $76 \%$ and $70 \%$ mortality on green stink bug respectively. The lethal period of the field and commercial B. bassiana are 3.70 days and 3.72 days respectively on aphid, and 5.44 days and 4.58 days on green stink bug. The virulence value of both inocula are 0.271 and 0.268 on aphids, and 0.195 and 0.245 on green stink bug. The virulence of both inocula is not significantly different. This results suggests that the commercial inoculum $B$. bassiana at $1 \times 10^{7}$ conidia/ml of concentration is less effective than the field inoculum B. bassiana as control agent on aphid.
\end{abstract}

Key words : virulence, Beauveria bassiana, aphid, green stink bug

\section{PENDAHULUAN}

Kutudaun (Aphis spp.) dan kepik hijau (Nezara viridula $\mathrm{L}$.) termasuk hama-hama yang penting pada tanaman kacang-kacangan (Kalshoven, 1981; Saleh, 2007; Balitkabi, 2008). Kutudaun sering dijumpai dengan populasi yang tinggi dan sekaligus berperan sebagai vektor penyakit virus pada tanaman kacang-kacangan (Saleh, 2007). Adapun kepik hijau sudah lama dikenal sebagai hama utama tanaman kedelai yang sebaran geografisnya cukup luas (Tengkano et al., 1988). Hama ini juga dapat menyerang banyak tumbuhan inang seperti kacang-kacangan, kentang, kapas, cabai, dan tembakau (Kalshoven, 1981). Menurut Tengkano et al., (2007) dari survai pada tahun 2003 diketahui bahwa kepik hijau merupakan salah satu di antara tiga hama yang sangat penting, yang penyebarannya meliputi di 32 lokasi survai di 8 kabupaten di Provinsi Lampung. Selain banyak ditemui di Indonesia dan Asia, hama tersebut juga sebagai perusak tanaman kedelai di Afrika, Australia, dan Amerika Serikat. Sudah sejak lama di Provinsi
Lampung permasalahan hama pada tanaman palawija khususnya kacang-kacangan banyak mengalami kendala, misalnya berbagai kasus resurjensi hama akibat penggunaan pestisida yang berlebihan (Susilo et al., 1994).

Dalam rangka mendukung pengembangan metode pengendalian hama yang berwawasan lingkungan, diperlukan kajian tentang peranan musuh alami sebagai agensia pengendali hama. Salah satu agensia hayati yang potensial sebagai sarana pengendali hama adalah jamur Beauveria bassiana (US EPA, 2006; Tengkano et al., 2007; Balitkabi, 2008).

Jamur ini sejak lama diketahui memiliki potensi sebagai agensia hayati yang dapat mengendalikan populasi serangga. Pemanfaatannya semakin luas, lebih dari 100 spesies hama sasaran meliputi beberapa ordo termasuk Coleoptera, Homoptera, Diptera, Lepidopera, dan Hymenoptera. Selain itu Beauveria bassiana (Bals.) Vuill. aman bagi serangga bukan sasaran, terutama serangga berguna dan musuh alami (Soetopo \& Indrayani, 2007; Thungrabeab \& Tongma, 2007). Di

\footnotetext{
Jurusan Proteksi Tanaman, Fakultas Pertanian, Universitas Lampung, J1. Prof. Sumantri Brodjonegoro No. 1 Bandar Lampung 35145. Email : indri1919@gmail.com
} 
Indonesia $B$. bassiana telah digunakan untuk mengendalikan kumbang penggerek buah kopi Hypothenemus hampei dan penggerek batang kakao Zeuzera coffeae (Kalshoven, 1981). Pada tahun 1993/ 1994, jamur ini juga telah digunakan secara luas untuk mengendalikan penggerek buah kakao Conopomorpha cramerella di daerah Aceh, Sumatera Utara, Lampung, Jawa Timur, dan Timor Timur (Haryono et al., 1993).

Kegiatan pembiakan jamur B. bassiana telah banyak dilakukan, baik oleh lembaga pemerintah seperti Laboratorium Balai Proteksi Tanaman di sejumlah daerah, berbagai institusi penelitian, maupun perusahaan komersial. Natural BVR adalah salah satu contoh insektisida mikroba berbahan aktif B. bassiana yang diformulasikan oleh PT. Natural Nusantara dan sudah diperdagangkan secara luas.

Suatu isolat atau biakan entomopatogen sebelum direkomendasikan untuk digunakan sebagai agensia pengendali hama di lapangan seyogyanya telah dikuantifikasi dengan cermat potensinya. Potensi suatu patogen dapat diketahui dengan menghitung besarnya daya infeksi patogen itu terhadap inangnya. Daya infeksi merupakan banyaknya inang yang secara positif mati akibat patogen tersebut. Inang dikatakan terinfeksi oleh patogen jika dapat menunjukkan gejala khas penyakit yang ditimbulkan oleh patogen tersebut (Nugroho et al., 1999).

Sehubungan dengan pentingnya mengetahui besarnya potensi berbagai isolat atau biakan $B$. bassiana yang tersedia sebelum digunakan secara lebih luas di lapangan, maka penelitian ini dilaksanakan. Tujuan penelitian ini adalah untuk mempelajari aspekaspek patogenisitas jamur B. bassiana yang berasal dari lapangan dan B. bassiana komersial terhadap dua hama penting tanaman kacang-kacangan yaitu kutudaun dan kepik hijau di laboratorium.

\section{METODE PENELITIAN}

Penelitian ini dilaksanakan pada bulan September sampai dengan November 2006 di Laboratorium Hama dan Penyakit Tumbuhan, Jurusan Proteksi Tanaman Fakultas Pertanian, Universitas Lampung.

Kutudaun (Aphis sp.) dan kepik hijau (Nezara viridula) diperoleh dari pertanaman kacang-kacangan pada lahan petani di Gedungmeneng kemudian dibiakkan secara terpisah pada tanaman kacang panjang (Vigna unguiculata) yang ditanam pada polibag yang diberi sungkup plastik mika berukuran diameter $30 \mathrm{~cm}$ dan tinggi $70 \mathrm{~cm}$.
Inokulum Beauveria bassiana lapang diisolasi dari belalang yang mati terinfeksi oleh jamur tersebut yang telah diisolasi dan dibiakkan di Laboratorium Biocontrol Bagian Riset dan Pengembangan PT Gunung Madu Plantations, Lampung Tengah. Adapun inokulum B. bassiana komersial digunakan insektisida mikroba berbahan aktif konidia. B. bassiana (nama dagang Natural BVR) yang diproduksi oleh PT. Natural Nusantara Yogyakarta serta telah diperdagangkan pada toko-toko sarana pertanian.

Penelitian ini terdiri atas dua set percobaan yang masing-masing disusun dalam Rancangan Acak Lengkap dengan 5 ulangan. Set percobaan pertama ialah aplikasi $B$. bassiana terhadap kutudaun dengan 3 perlakuan (D1: kontrol = aplikasi tanpa suspensi $B$. bassiana; D2 : aplikasi suspensi $B$. bassiana lapang; dan D3 : aplikasi B. bassiana komersial). Set percobaan kedua ialah aplikasi $B$. bassiana terhadap kepik hijau dengan 3 perlakuan $(\mathrm{H1}$ : kontrol $=$ aplikasi tanpa suspensi B. bassiana; $\mathrm{H} 2$ : aplikasi suspensi $B$. bassiana lapang; dan H3 : aplikasi $B$. bassiana komersial). Seluruh perlakuan aplikasi suspensi $B$. bassiana dilakukan dengan konsentrasi $10^{7}$ konidia per mililiter aquades. Adapun satuan-satuan percobaan masing-masing berupa stoples plastik yang berisi sepucuk tanaman kacang panjang yang diserang oleh kutudaun sebanyak \pm 180 ekor, serta stoples plastik yang berisi polong kacang panjang dengan 10 ekor nimfa kepik hijau instar 3 . Aplikasi suspensi B. bassiana terhadap koloni kutudaun pada pucuk kacang panjang dilakukan dengan pipet tetes, sedangkan aplikasi suspensi $B$. bassiana terhadap kepik hijau dilakukan dengan cara mencelupkan kepik hijau ke dalam suspensi jamur selama 10 detik hingga seluruh tubuh kepik terbasahi.

Pengamatan dilakukan setiap hari hingga 15 hari setelah aplikasi atau sampai tidak ada lagi penambahan kematian serangga uji selama 3 hari berturut-turut. Kutudaun dan kepik hijau yang mati diidentifikasi ulang di laboratorium untuk membuktikan bahwa kematiannya disebabkan oleh $B$. bassiana. Identifikasi kematian dilakukan dengan melembabkan serangga uji tersebut di dalam cawan petri yang diberi alas kertas saring yang dibasahi dengan aquades. Kematian serangga uji terbukti disebabkan oleh B. bassiana jika pada serangga uji yang dilembabkan muncul massa jamur berwarna putih serta dilanjutkan dengan pemeriksaan jamur tersebut secara mikroskopik. Adapun variabel yang diamati meliputi mortalitas dan waktu kematian serangga uji yang selanjutnya dihitung nilai periode letal dan virulensi 
B. bassiana terhadap serangga uji menggunakan rumus (Susilo et al., 1993) :

Periode letal $(\mathrm{T})=\left[\sum\left(\mathrm{H}_{\mathrm{i}} \times \mathrm{M}_{\mathrm{i}}\right)\right] /\left[\sum\left(\mathrm{M}_{\mathrm{i}}\right)\right]$; dan

Virulensi $(\delta)=1 / \mathrm{T}$

dengan $\mathrm{H}_{\mathrm{i}}$ : hari ke-i terjadinya kematian, dan $\mathrm{M}_{\mathrm{i}}$ : jumlah serangga uji yang mati pada hari ke-i. Data yang terhimpun dianalisis dengan sidik ragam serta dilanjutkan dengan uji BNT pada taraf nyata $1 \%$ atau $5 \%$.

\section{HASIL DAN PEMBAHASAN}

Hasil pengamatan menunjukkan bahwa kutudaun dan kepik hijau yang diberi perlakuan jamur $B$. bassiana yang berasal dari lapang maupun $B$. bassiana dari formulasi komersial mengalami infeksi dan memperlihatkan gejala berkurangnya aktivitas gerak dan makan serta berlanjut dengan kematian.

Tanda awal kematian serangga tersebut ialah tubuhnya kaku serta warnanya menjadi kusam. Pada kutudaun, tanda ini tidak begitu mudah dilihat dan baru tampak dengan jelas bahwa kutudaun telah mati ketika tidak lagi berada pada pucuk daun tanaman kacang panjang yang digunakan sebagai pakannya tetapi telah jatuh pada alas stoples tempat satuan-satuan percobaan ini berlangsung. Lain halnya tanda kematian kepik hijau yang lebih mudah dilihat. Diduga hal inilah yang menyebabkan data mortalitas kutudaun baru bisa teramati pada hari ke-3 setelah aplikasi, sedangkan data mortalitas kepik hijau sudah teramati sejak hari ke-1 setelah aplikasi. Hal demikian terlihat baik pada aplikasi $B$. bassiana lapang maupun $B$. bassiana komersial (Gambar 1 dan Gambar 2).

Proses mortalitas kutudaun yang disebabkan oleh $B$. bassiana lapang maupun $B$. bassiana komersial berlangsung relatif singkat yaitu sejak hari ke-3 hingga hari ke-5 setelah aplikasi (Gambar 1). Pada tiga hari berikutnya tidak terlihat lagi adanya kematian yang baru. Adapun proses kematian kepik hijau oleh aplikasi $B$. bassiana terjadi dalam waktu yang lebih panjang yaitu sejak hari pertama hingga hari ke-15 setelah aplikasi (Gambar 2). Pada percobaan Nugroho et al. (1999) yang menggunakan jamur Metarhizium anisopliae dan kepik hijau terlihat bahwa kematian harian kepik itu berlangsung hingga hari ke-14 dan tidak terjadi lagi kematian yang baru sesudahnya.

Proses infeksi $B$. bassiana yang menimbulkan kematian kutudaun yang lebih singkat dibandingkan dengan proses kematian kepik hijau ini diduga terkait dengan ukuran (dan bobot) tubuh kutudaun yang lebih kecil dan lama waktu daur hidup kutudaun (13 - 18 hari) yang lebih pendek daripada daur hidup kepik hijau (60 80 hari) (Kalshoven, 1981). Perbedaan proses infeksi ini mungkin juga berhubungan dengan jumlah serangga uji yang digunakan pada tiap satuan percobaan (180 ekor kutudaun, sedangkan kepik hijau 10 ekor). Banyaknya populasi serangga yang bersama-sama berada dalam suatu patosistem akan berinteraksi sesamanya dan menimbulkan potensi kontak antara inokulum dengan serangga inang yang sakit maupun yang sehat. Besarnya

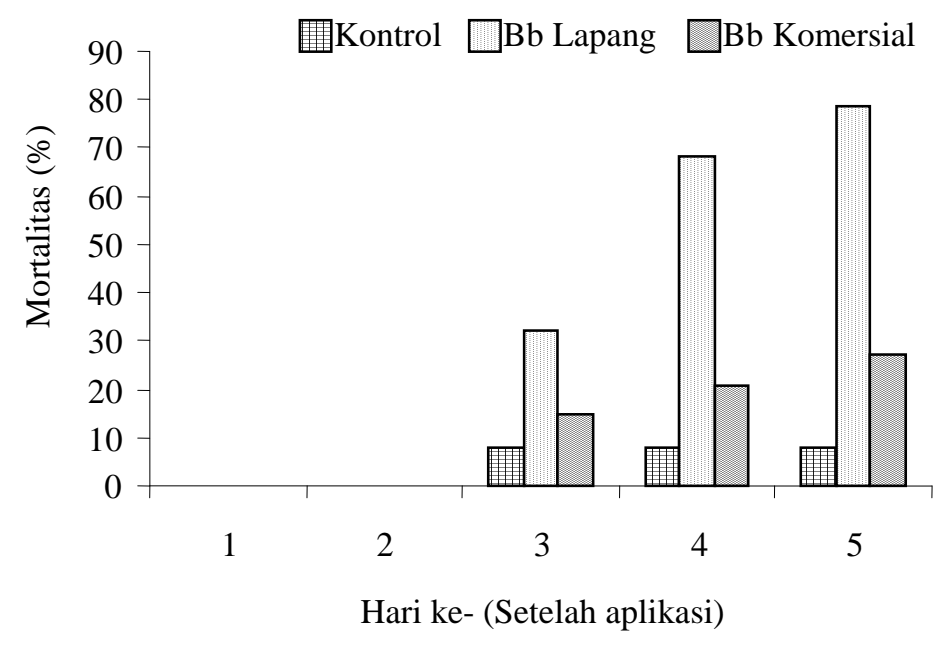

Gambar 1. Mortalitas harian kumulatif kutudaun (Aphis spp.) akibat aplikasi B. bassiana lapang dan B. bassiana komersial 
困Kontrol $\square$ Bb Lapang $\square$ Bb Komersial

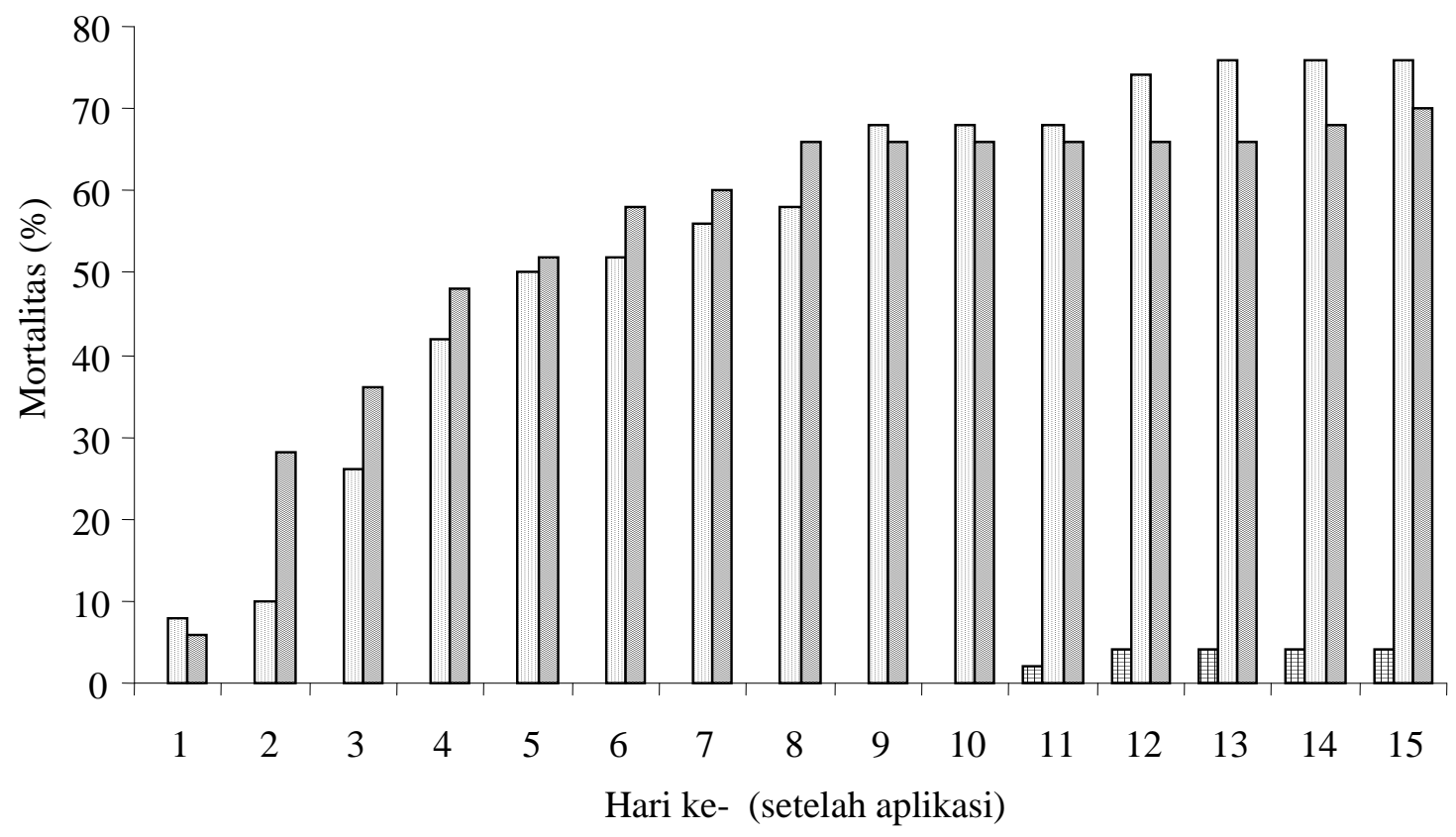

Gambar 2. Mortalitas harian kumulatif kepik hijau (Nezara viridula) akibat aplikasi B. bassiana lapang dan B. bassiana komersial

Tabel 1. Pengaruh aplikasi jamur B. bassiana terhadap mortalitas kumulatif kutudaun (5 hsa) dan kepik hijau (15 hsa) di laboratorium

\begin{tabular}{lcc}
\hline \multirow{2}{*}{ Perlakuan } & \multicolumn{2}{c}{ Mortalitas (\%) } \\
\cline { 2 - 3 } & Kutudaun & Kepik hijau \\
\hline Kontrol (tanpa aplikasi B. bassiana) & $8,06 \mathrm{a}$ & $4 \mathrm{a}$ \\
Aplikasi B. bassiana lapang & $78,80 \mathrm{c}$ & $76 \mathrm{~b}$ \\
Aplikasi B. bassiana komersial & $27,42 \mathrm{~b}$ & $70 \mathrm{~b}$ \\
\hline
\end{tabular}

Keterangan : angka-angka sekolom yang diikuti notasi huruf yang sama berarti tidak berbeda menurut uji BNT pada taraf nyata $5 \%$

Tabel 2. Pengaruh aplikasi jamur B. bassiana terhadap periode letal dan virulensinya terhadap kutudaun dan kepik hijau di laboratorium

\begin{tabular}{|c|c|c|c|c|}
\hline \multirow{2}{*}{ Perlakuan } & \multicolumn{2}{|c|}{ Periode letal (hari) } & \multicolumn{2}{|c|}{ Virulensi } \\
\hline & Kutudaun & Kepik hijau & Kutudaun & Kepik hijau \\
\hline Kontrol (tanpa aplikasi B. bassiana) & & 0 & & 0 \\
\hline Aplikasi B. bassiana lapang & $3,70 \mathrm{~b}$ & $5,44 \mathrm{~b}$ & $0,271 \mathrm{~b}$ & $0,195 \mathrm{~b}$ \\
\hline Aplikasi B. bassiana komersial & $3,72 \mathrm{~b}$ & $4,58 \mathrm{~b}$ & $0,268 \mathrm{~b}$ & $0,248 \mathrm{~b}$ \\
\hline
\end{tabular}

Keterangan : angka-angka sekolom yang diikuti notasi huruf yang sama berarti tidak berbeda menurut uji BNT pada taraf nyata $5 \%$ 
potensi kontak ini berbanding lurus dengan daya infeksi patogennya (Dewi et al., 1998). Penelitian aplikasi jamur entomopatogen $M$. anisopliae yang masih sekerabat dengan B. bassiana (Deuteromycotina: Hyphomycetes) terhadap kepik hijau (Nugroho et al., 1999) dan kutudaun kedelai (Arianti et al., 2000) menunjukkan bahwa daya infeksi jamur meningkat seiring dengan peningkatan jumlah inang yang sudah terinfeksi maupun inang yang belum terinfeksi pada sekumpulan populasi inang .

Hasil penelitian menunjukkan bahwa B. bassiana lapang maupun komersial yang diuji mampu menimbulkan mortalitas kutudaun maupun kepik hijau. Aplikasi B. bassiana lapang tampak menimbulkan mortalitas kumulatif kutudaun harian (Gambar 1) maupun mortalitas kumulatif pada akhir pengamatan yang nyata lebih tinggi $(78,8 \%)$ daripada perlakuan $B$. bassiana komersial $(27,42 \%)$ (Tabel 1). Perbedaan mortalitas yang terjadi diduga disebabkan adanya perbedaan isolat atau inokulum-inokulum B. bassiana tersebut.

Trisawa \& Laba (2006) yang meneliti keefektifan B. bassiana dengan konsentrasi 10 gram/liter terhadap kepik renda lada Diconocoris hewetti (Hemiptera : Tingidae) mendapatkan hasil adanya perbedaan yang nyata pada mortalitas kepik renda pada hari ke- 9 setelah aplikasi, yaitu mortalitas sebesar $20 \%$ akibat aplikasi $B$. bassiana isolat ED3 dan mortalitas sebesar $80 \%$ akibat B. bassiana isolat ED6. Demikian pula hasil penelitian Soetopo et al. (2007) bahwa pada konsentrasi $1 \times 10^{9} \mathrm{konidia} / \mathrm{ml}$, B. bassiana isolat Bb4a dan BbEd10 dapat menyebabkan mortalitas larva Helicoverpa armigera masing-masing $87,5 \%$ dan $80,0 \%$, sedangkan isolat $\mathrm{Fb} 4$ hanya menimbulkan mortalitas $45 \%$. Sedangkan penelitian Todorova et al. (2002) yang menguji patogenisitas 6 isolat $B$. bassiana terhadap kepik pentatomid Perillus bioculatus memperoleh hasil bahwa 5 isolat $B$. bassiana sangat patogenik yakni pada hari ke-8 dapat menimbulkan mortalitas serangga uji $77 \%$ atau lebih, sedangkan satu isolat lainnya hanya menimbulkan kematian 11\% nimfa kepik tersebut.

Kematian serangga uji yang disebabkan oleh patogen serangga merupakan tanda paling nyata telah terjadinya proses infeksi. Proses infeksi sesungguhnya dimulai sejak inokulasi atau pendedahan (expose) inokulum patogen terhadap inang. Jangka waktu sejak inokulasi sampai terjadinya kematian inang disebut dengan periode letal patosistem yang bersangkutan, sedangkan kebalikan (invers) dari periode letal adalah besaran virulensi patogen tersebut (Susilo et al., 1993).

Infeksi B. bassiana yang berasal dari lapang maupun komersial yang menimbulkan kematian pada kutudaun dalam kisaran waktu $3-5$ hari (Gambar 1) memiliki nilai periode letal berturut-turut sebesar 3,70 hari dan 3,72 hari serta nilai virulensi berturut-turut 0,271 dan 0,268 (Tabel 2). Meskipun besarnya periode letal dan nilai virulensi $B$. bassiana lapang maupun komersial secara statistik tidak berbeda tetapi mortalitas kumulatif kutudaun akibat aplikasi inokulum jamur B. bassiana lapang sebesar $78,80 \%$ berbeda nyata dengan mortalitas yang ditimbulkan oleh inokulum komersial $(27,42 \%)$.

Pada percobaan ini terlihat bahwa inokulum B. bassiana komersial kurang efektif menekan populasi kutudaun (mortalitas 27,42\%), namun tidak demikian halnya terhadap kepik hijau (mortalitas $70 \%$ ). Fenomena ini mengarah pada dugaan adanya perbedaan respon serangga target terhadap B. bassiana (Tohidin et al., 1993 ; Sabbahi et al., 2008). Pada hasil uji efikasi B. bassiana terhadap kepik Lygus lineolaris, Anthonomus signatus dan Otiorhyncus ovatus pada kosentrasi $1 \times 10^{8}$ konidia/ml menunjukkan bahwa kepik lebih rentan (waktu bertahan hidup hanya 4,41 hari) daripada kedua kumbang tersebut (waktu bertahan hidupnya berturut-turut mencapai 7,56 hari dan 8,29 hari) (Sabbahi et al., 2008).

Selain hal itu, juga dimungkinkan adanya pengaruh konsentrasi (kerapatan konidia) dari inokulum dalam proses infeksi suatu patogen terhadap inangnya (Kim et al., 2004).

Penelitian Baehaki \& Noviyanti (1993) mengindikasikan bahwa untuk menginfeksi wereng coklat padi dengan tingkat mortalitas $71 \%$, jamur M. anisopliae perlu diaplikasikan dengan kerapatan konidia $10^{15}$ dalam volume semprot 500 liter per hektar, sedangkan pada percobaan lain untuk menginfeksi ulat api Darna catenata dengan tingkat mortalitas $100 \%$ dibutuhkan kerapatan konidia $B$. bassiana sebesar 39,90 x 10\%/ml (Daud et al., 1993).

Oleh karenanya, rendahnya mortalitas kutudaun akibat aplikasi inokulum $B$. bassiana komersial mungkin karena kurangnya kerapatan konidia jamur tersebut. Hal ini sejalan dengan Prayogo (2006) bahwa salah satu upaya untuk menambah keefektifan suatu cendawan entomopatogen perlu dilakukan penentuan konsentrasi aplikasi yang tepat.

Adapun pada kepik hijau perlakuan B. bassiana lapang menimbulkan mortalitas $76 \%$, periode letal 5,44, dan nilai virulensi 0,195 . Hasil ini tidak berbeda dengan perlakuan $B$. bassiana komersial yang menimbulkan mortalitas $70 \%$, periode letal 4,58 dan virulensi 0,248 (Tabel 1 dan Tabel 2). Hal ini menunjukkan bahwa baik $B$. bassiana lapang maupun komersial memiliki keefektifan yang tidak berbeda terhadap kepik hijau. 


\section{SIMPULAN}

Dari hasil penelitian ini dapat disimpulkan bahwa:

1. Inokulum B. bassiana dari lapang (yang telah diisolasi dan dibiakkan di laboratorium Biocontrol PT Gunung Madu Plantations) dan B. bassiana komersial (Natural BVR) nyata bersifat patogenik dan dapat menimbulkan mortalitas kutudaun masing-masing sebesar $78,8 \%$ dan $27,42 \%$, serta dapat menimbulkan mortalitas kepik hijau masingmasing sebesar $76 \%$ dan $70 \%$.

2. Periode letal kedua inokulum B. bassiana tersebut pada kutudaun ialah 3,70 hari dan 3,72 hari, sedangkan pada kepik hijau 5,44 hari dan 4,58 hari.

3. Virulensi inokulum B. bassiana lapang dan B. bassiana komersial pada kutudaun berturut-turut sebesar 0,271 dan 0,268, sedangkan pada kepik hijau berturut-turut sebesar 0,195 dan 0,248.

4. Inokulum B. bassiana komersial (Natural BVR) pada konsentrasi $10^{7}$ konidia per mililiter - kurang efektif menekan populasi kutudaun dibandingkan inokulum B. bassiana lapang.

\section{SANWACANA}

Tulisan ini adalah bagian dari hasil kegiatan hibah penelitian dalam Program Hibah Kompetisi A2 Jurusan Proteksi Tanaman 2005/2006. Kepada Ibu Ir. Lestari Wibowo, M.P. dan Bapak Ir. Nuryasin, M.Si. disampaikan terimakasih atas masukan-masukan yang amat berharga. Ucapan serupa disampaikan kepada Sdr. Heni Lestari, S.P. dan Wiwik Prihartati, S.P. atas kerjasamanya yang baik dalam pelaksanaan penelitian ini.

\section{DAFTAR PUSTAKA}

Arianti, M.P.D., F.X. Susilo, \& Indriyati. 2000. Daya tular dan keterpautan kepadatan inokulum cendawan Metarhizium anisopliae pada kutudaun kedelai (Aphis glycines). J. Pen. Pengb. Wil. Lahan Kering 22 (1): 21-27.

Baehaki, S.E. \& Noviyanti. 1993. Pengaruh umur biakan Metarhizium anisopliae strain lokal Sukamandi terhadap perkembangan wereng coklat. Prosiding
Makalah Simposium Patologi Serangga I. Yogyakarta, 12-13 Oktober 1993. pp. 113-124.

Balitkabi (Balai Penelitian Tanaman Kacang-kacangan dan Umbi-umbian). 2008. Hama dan Penyakit Kedelai Penting dan Potensi Agensia Hayati di Jawa Timur. http://balitkabi.malang.te.net.id/ index.php. Diakses tanggal 20 Juni 2009.

Daud, I. D., A. Papulung, \& Mery. 1993. Efektivitas lima konsentrasi suspensi spora Beauveria bassiana Vuill. terhadap mortalitas tiga instar larva Darna catenata Snellen (Lepidoptera: Caenata). Prosiding Makalah Simposium Patologi Serangga I. Yogyakarta, 12-13 Oktober 1993. pp. 125-134.

Dewi, M., F.X. Susilo, \& A.M. Hariri. 1998. Daya infeksi, efisiensi penularan, dan periode letal penyakit muskardin hijau (Metarhizium anisopliae) pada wereng batang coklat padi (Nilaparvata lugens). Jurnal Penelitian Pertanian 9 (9): 156-166.

Haryono, H., S. Nuraini, \& Riyatno. 1993. Prospek penggunaan Beauveria bassiana untuk pengendalian hama tanaman perkebunan. Prosiding Makalah Simposium Patologi Serangga I. Yogyakarta, 12-13 Oktober 1993. pp. 75-81.

Kalshoven, L.G.E. 1981. The Pests of Crops in Indonesia. Revised and translated by P.A. Van der Laan \& G.H.L. Rothschild. PT Ichtiar Baruvan Hoeve. Jakarta.

Kim, J.J., M.H. Lee, C.S.Yoon, H.S. Kim, J.K. Yoo, \& K.C. Kim. 2004. Control of cotton aphid and greenhouse whitefly with fungal pathogen. http://www.agnet.org/library/eb/502b. Diakses tanggal 20 Juni 2009.

Nugroho, A.N., F.X. Susilo, \& Indriyati. 1999. Potensi kontak antara inokulum dan inang menentukan efisiensi penularan penyakit muskardin hijau pada kepik hijau kedelai. J. Pen. Pengb. Wil. Lahan Kering. 24 : 28-36. 
Prayogo, Y. 2006. Upaya mempertahankan keefektifan cendawan entomopatogen untuk mengendalikan hama tanaman pangan. Jurnal Litbang Pertanian 25 (2): 47-54.

Sabbahi, R., A. Merzouki, \& C. Guertin. 2008. Efficacy of Beauveria bassiana against the Strawberry pest, Lygus lineolaris, Anthonomus signatus and Otiorhynchus ovatus. J. Appl. Entomology 132(2): 151-160

Saleh, N. 2007. Sistem Produksi Kacang-kacangan untuk Menghasilkan Benih Bebas Virus. Iptek Tanaman Pangan 2 (1): 66-78. http:// www.puslittan.bogor.net/. Diakses tanggal 20 Juni 2009.

Susilo, F.X., R. Hasibuan, G.L. Nordin, \& G.C. Brown. 1993. The concept of threshold density in insect pathology: A Theoritical and experimental study on Tetranychus - Neozygites mycosis. Prosiding Makalah Simposium Patologi Serangga I. Yogyakarta, 12-13 Oktober 1993. pp. 29-37.

Susilo, F.X., I.G. Swibawa, M. Solikhin, \& S.W. Supriyono. 1994. Effect of pesticide use on nontarget soybean arthropods in Central Lampung, Indonesia. In: Environmental Toxicology in South East Asia (B. Widianarko, K. Vink, \& N.M. van Straalen, Eds.). VU Univ. Press. Amsterdam. pp. 129-144.

Soetopo, D. \& I. Indrayani. 2007. Status Teknologi dan Prospek Beauveria bassiana Untuk Pengendalian Serangga Hama Tanaman Perkebunan Yang Ramah Lingkungan. Perspektif 6 (1): 29-46. http://perkebunan litbang.go.id/publikasi/perspektif. Diakses tanggal 20 Juni 2009.

Soetopo, D., S.G. Reyes, \& D.R. Santiago. 2007. Laboratory assay of Beauveria bassiana against Helicoverpa armigera. Proceedings on The $I^{\text {st }}$ International Conference of Crop Security 2005 at Brawijaya University, Malang, September $20^{\text {th }}-22^{\text {nd }}, 2005$, pp.46-55.
Tengkano, W., T. Okada, L. Taulu, \& Suhargiyantoro. 1988. Jenis dan penyebaran hama pengisap polong di Indonesia. Seminar Hasil Penelitian Hama Kedelai. Balittan Bogor, 6 Desember 1988.

Tengkano, W., Supriyatin, Suharsono, Bedjo, P. Yusmani, \& Purwantoro. 2007. Status Hama Kedelai dan Musuh Alami pada Agroekosistem Lahan Kering Masam Lampung. Iptek Tanaman Pangan No. 3: 93-109. http://www.puslittan.bogor.net/. Diakses tanggal 20 Juni 2009.

Thungrabeab, M. \& S. Tongma. 2007. Effect Of Entomopathogenic Fungi, Beauveria bassiana (Balsam) and Metarhizium anisopliae (Metsch) on Non Target Insects. J. KMITL Sci. Tech. 7 (S1): 8-12.

Todorova, S.I., C. Cloutier, J.C. Côté, \& D. Coderre. 2002. Pathogenicity of six isolates of Beauveria bassiana (Balsamo) Vuillemin (Deuteromycotina, Hyphomycetes) to Perillus bioculatus (F) (Hem., Pentatomidae). J. Appl. Entomology 126 (4): 182-185.

Tohidin, A.T. Lisrianto, \& B.P. Machdar. 1993. Daya bunuh jamur entomopatogen Beauveria bassiana (Balsamo) Vuillemin terhadap Leptocorisa acuta di rumah kaca. Prosiding Makalah Simposium Patologi Serangga I. Yogyakarta, 12-13 Oktober 1993. pp. 135-143.

Trisawa, I.M., \& I.W. Laba. 2006. Keefektifan Beauveria bassiana dan Spicaria sp. Terhadap kepik renda lada Diconocoris hewetti (Dist.) (Hemiptera: Tingidae). Bull. Littro. 17 (2): 99106.

US EPA. 2006. Beauveria bassiana strain GHA(128924) Technical Document. RE. http:/ /www.epa.gov/pesticides/biopesticides/ ingredients/tech docs/tech 128924.html. Diakses tanggal 20 Juni 2009. 